\title{
Influence of uterine bacterial contamination after parturition on ovarian dominant follicle selection and follicle growth and function in cattle
}

\author{
I. M. Sheldon ${ }^{1}$, D. E. Noakes ${ }^{1}$, A. N. Rycroft ${ }^{2}$, \\ D. U. Pfeiffer ${ }^{1}$ and H. Dobson ${ }^{3}$ \\ ${ }^{1}$ Department of Veterinary Clinical Science and ${ }^{2}$ Department of Pathology and Infectious \\ Diseases, Royal Veterinary College, Hawkshead Lane, North Mymms, Hatfield AL9 7TA, UK; \\ and ${ }^{3}$ Department of Veterinary Clinical Science and Animal Husbandry, University of \\ Liverpool, Leahurst, Chester High Road, Neston CH64 7TE, UK
}

First postpartum dominant follicles are preferentially selected in the ovary contralateral to the previously gravid uterine horn. The aim of the present study was to test the hypothesis that uterine bacterial contamination alters the location of ovarian follicle emergence and selection, and inhibits follicle growth and function. Swabs were collected from the uterine body lumen of cattle on days 7, 14, 21 and 28 after parturition. Bacteria were identified by aerobic and anaerobic culture; bacterial growth was scored semiquantitatively and animals were categorized into standard or high bacterial contamination categories on the basis of the number of colonies detected. Follicular growth and function were monitored by daily transrectal ultrasonography, and estimation of plasma $\mathrm{FSH}$, oestradiol and progesterone concentrations. There was no effect of

\section{Introduction}

After parturition, an increase in plasma FSH concentration is followed by the emergence of a wave of several follicles 4-6 $\mathrm{mm}$ in diameter and subsequent selection of a single dominant follicle (Beam and Butler, 1997; Crowe et al., 1998). Sequential transrectal ultrasonography has revealed that the first postpartum dominant follicle is preferentially selected in the ovary contralateral to the previously gravid uterine horn (Kamimura et al., 1993; Sheldon et al., 2002). This is important because the presence of a large follicle in the ovary ipsilateral to the previously gravid uterine horn within 4 weeks of parturition, although less frequent, is associated with improved fertility (Bonnett et al., 1993; Sheldon et al., 2000).

Suppression of folliculogenesis in the ipsilateral ovary decreases as the postpartum interval advances, concurrent with the disappearance of the corpus luteum of pregnancy, uterine involution and elimination of the ubiquitous uterine bacterial contamination after parturition (Elliot et al., 1968;

Email: msheldon@rvc.ac.uk bacterial contamination on plasma FSH concentration profiles or emergence of the ovarian follicle wave. When uterine bacterial growth scores were high on day 7 or day 21 after parturition, fewer first $(1 / 20$ versus $15 / 50 ; P<$ $0.05)$ or second $(1 / 11$ versus $13 / 32 ; P<0.05)$ dominant follicles were selected in the ipsilateral compared with the contralateral ovary, respectively. The diameter of the first dominant follicle was smaller in animals with a high day 7 bacterial score $(P<\mathbf{0 . 0 0 1})$, dominant follicle growth was slower $(P<0.05)$ and oestradiol secretion was decreased $(P<0.05)$. The present study provides evidence for an effect of the uterus on the ovary after parturition, whereby uterine bacteria have a contemporaneous localized effect on ovarian follicle selection and subsequent growth and function, but not on initial emergence.
Sawyer, 1995; Sheldon et al., 2000). Suppression of folliculogenesis in the ipsilateral ovary could be explained by an inhibitory local effect of the regressing corpus luteum of pregnancy or the previously gravid uterine horn or its contents (Dufour and Roy, 1985). However, the removal of the corpus luteum of pregnancy by administration of $\mathrm{PGF}_{2 \alpha}$ before parturition did not influence the growth, function or ovarian location of the first postpartum dominant follicle (Sheldon et al., 2002). In addition, the diameter of the uterine horn did not influence the ovarian location of the first postpartum dominant follicle (I. M. Sheldon and H. Dobson, unpublished).

Although the previously gravid uterine horn was not identified, in one study ovarian follicles were smaller after parturition in cattle with a uterine bacterial infection (Peter and Bosu, 1988). Furthermore, inflammatory mediators such as bacterial endotoxin and immune mediators such as cytokines disturb the hormonal interactions that control normal cyclical ovarian function (Rivest et al., 1993; Battaglia et al., 1999; Williams et al., 2001). Intracerebral or intravenous administration of inflammatory mediators disrupts GnRH release from the hypothalamus and LH secretion from the pituitary. However, a surprising inhibition of 
follicular oestradiol secretion after administration of endotoxin, in the face of adequate plasma $\mathrm{LH}$ concentrations, led to the suggestion of an additional effect at the ovary (Xiao et al., 1998; Battaglia et al., 2000). Despite these observations, few human or animal studies have focused on the impact of inflammatory mediators on the ovary, particularly under normal pathophysiological situations.

The aim of the present study was to test the hypothesis that postpartum uterine bacterial contamination alters the location of ovarian follicle emergence and selection, and inhibits growth and function of the dominant follicle.

\section{Materials and Methods}

\section{Animals}

All procedures were performed under the Animals (Scientific Procedures) Act 1986 regulations for experiments on living animals, administered by the UK Home Office. In addition, experimental protocols were approved by the Royal Veterinary College Ethical Review Committee.

A dairy herd of 90 Holstein-Friesian cows, with an annual average milk yield of 6800 litres and a rolling herd mean somatic cell count of $8.4 \times 10^{4}$ cells $\mathrm{ml}^{-1}$, was selected for the study on the basis of accurate farm records. All of the cows had been mated with Holstein-Friesian bulls and were pregnant. Animals with a history of Caesarean operation or the presence of vaginal lacerations, acute mastitis, lameness, abdominal disorders or other intercurrent disease were excluded from the study on the basis of daily clinical examination, to remove any confounding influence of non-uterine bacterial infection during the study period (Skinner et al., 1991; Scott et al., 1992; Horadagoda et al., 1999). Seventy Holstein-Friesian cows were included in the study during a 1 year period. No antimicrobial treatments were administered during the study.

\section{Clinical examination}

The genital tract of each cow was examined daily from day 7 to day 28 after parturition using transrectal palpation and ultrasonography with a 7.5 $\mathrm{MHz}$ linear array transducer (Aloka SSD 210 DXII; BCF Technology, Livingstone). The previously gravid uterine horn was identified as being longer and of greater diameter than the contralateral horn. Follicles were defined as non-echogenic (black) spherical structures with a clear demarcation between the follicular wall and antrum. A corpus luteum was defined as a grainy echogenic structure that had a well-defined border with the less echogenic ovarian stroma; in some corpora lutea there was a non-echogenic lacuna. The numbers of ovarian follicles $\geqslant 4 \mathrm{~mm}$ in diameter and corpora lutea in each ovary were counted, and each maximum diameter was measured using the instrument's internal callipers. When the image of the structure being scanned was not spherical, the diameter was estimated by averaging two $90^{\circ}$ dimensions.
A dominant follicle was defined as the largest follicle in the ovary with internal diameter $>10 \mathrm{~mm}$ in the absence of other growing follicles (Dobson et al., 2000). A dominant follicle and cohorts were defined as a follicular wave (Dobson et al., 2000). The first day of dominance within a follicular wave was determined retrospectively as the day on which the dominant follicle initially exceeded $10 \mathrm{~mm}$ in diameter. The number of follicles in a wave $\geqslant 4 \mathrm{~mm}$ or $>10 \mathrm{~mm}$ in diameter was based on emergence of the follicles at the same or consecutive examinations (Ginther et al., 1996). The day of ovulation was defined as the day on which the dominant follicle was last scanned before its sudden disappearance and the subsequent appearance of a corpus luteum in the same location. Luteinization was confirmed retrospectively by a subsequent increase in plasma progesterone concentration to $>1 \mathrm{ng} \mathrm{ml}^{-1}$. A persistent follicle (follicular cyst) was defined as a follicle with internal diameter $>10 \mathrm{~mm}$ that persisted for $>5$ consecutive days and did not ovulate (Dobson et al., 2000).

\section{Uterine swab collection and bacteriology}

A transcervical guarded swab was collected from the uterine body of each cow on days 7, 14, 21 and 28 after parturition using a previously validated method (Noakes et al., 1989). The swab was transferred to a bijou bottle containing Stuart transport medium (Unipath, Basingstoke) and was cultured within $1 \mathrm{~h}$ of collection at the on-site bacteriology laboratory. Swabs were cultured aerobically and anaerobically on pre-equilibrated sheep blood agar (Unipath), and aerobically on MacConkey agar (Unipath). Identification of bacteria was based on the characteristics of the colony, Gram stain, morphology, haemolysis, biochemical profile (API systems, BioMérieux, Basingstoke) and other standard tests (Barrow and Feltham, 1993). Bacterial growth on the culture plates was scored semiquantitatively, dependent on the number of bacterial colonies detected on the plate: 0 : no growth; $1:<10$ colonies; 2: 10-100 colonies; 3: 100-500 colonies; and 4: $>500$ colonies (Noakes et al., 1991). The bacterial growth score on days 7, 14, 21 and 28 was the sum of the scores for each of the bacterial isolates, and the total bacterial growth score for each cow was the sum of the individual bacterial growth scores for all four uterine swabs. The uterine bacterial scores at each time point were used to categorize cows into categories of standard or high bacterial contamination on days 7, 14, 21 and 28. The standard category was defined as the lower $75 \%$ quartile bacterial score and the high contamination category as the upper $25 \%$. In addition, bacteria were categorized on the basis of expected pathogenic potential within the uterus (Ruder et al., 1981; Olson et al., 1984; Farin et al., 1989; Noakes et al., 1989, 1991; Bonnett et al., 1993). The categories were: (1) pathogens known to cause endometrial lesions; (2) other recognized uterine pathogens; and (3) bacteria not recognized as uterine pathogens (see Table 1). These bacterial pathogenicity categories were used to group cows 
Table 1. Categorization of bacteria, isolated by aerobic and anaerobic culture of uterine swabs from cattle, based on their potential pathogenicity

\begin{tabular}{lll}
\hline & \multicolumn{1}{c}{ Bacterial category } & \\
\hline 1 & \multicolumn{1}{c}{2} & 3 \\
\hline Arcanobacterium pyogenes & Acinetobacter spp & Aerococcus viridans \\
Prevotella spp & Bacillus licheniformis & Clostridium butyricum \\
Escherichia coli & Enterococcus faecalis & Clostridium perfringens \\
Fusobacterium necrophorum & Haemophilus somnus & Corynebacterium spp \\
Fusobacterium nucleatum & Mannhiemia haemolytica & Enterobacter aerogenes \\
& Pasteurella multocida & Klebsiella pneumoniae \\
& Peptostreptococcus spp & Micrococcus spp \\
& Staphylococcus aureus (coagulase + ) & Providencia rettgeri \\
& Streptococcus uberis & Providencia stuartii \\
& & Proteus spp \\
& & Proprionobacterium granulosa \\
& & Staphylococcus spp (coagulase -) \\
& & S-Haemolytic Streptococci \\
\end{tabular}

for the presence of the most pathogenic bacteria on days 7 , 14, 21 or 28 for statistical analysis, with a fourth group in which no bacteria were isolated (Laven et al., 2000).

\section{Blood sampling and hormone assays}

Blood samples were collected once a day from day 7 to day 21 after parturition, from the coccygeal vein or artery into evacuated heparinized tubes (BD Vacutainer Systems, Plymouth) and transported on ice to the laboratory. Within $30 \mathrm{~min}$, plasma was separated by centrifugation at $2200 \mathrm{~g}$ for $10 \mathrm{~min}$, harvested and stored at $-20^{\circ} \mathrm{C}$.

Oestradiol concentration was estimated in duplicate by a previously characterized radioimmunoassay (Estradiol MAIA; Serono Diagnostics Ltd, Woking) using diethyl etherextracted plasma (Mann et al., 1995). The mean intra( $n=12$ samples) and interassay ( $n=3$ assays) coefficients of variation were 8.1 and $13.1 \%$, respectively, for a $0.9 \mathrm{pg}$ $\mathrm{ml}^{-1}$ sample, and the minimum detectable quantity was $0.24 \mathrm{pg} \mathrm{ml}^{-1}$. Progesterone concentration was estimated in duplicate using a commercial ELISA kit (Ridgeway Science, Gloucester). The intra- ( $n=10$ samples) and interassay ( $n=3$ assays) coefficients of variation were 6.5 and $11.2 \%$, respectively, for a $1.7 \mathrm{ng} \mathrm{ml}^{-1}$ sample, and the minimum detectable quantity was $0.6 \mathrm{ng} \mathrm{ml}^{-1}$. FSH concentration was estimated in duplicate by a previously characterized radioimmunoassay (Dobson et al., 2000). The standard used for the FSH assay was AFP 5679C RP-1. The intra( $n=20$ samples) and interassay ( $n=3$ assays) coefficients of variation were 3.4 and $4.7 \%$, respectively, for a $1.2 \mathrm{ng} \mathrm{ml}^{-1}$ sample, and the minimum detectable quantity was $0.12 \mathrm{ng} \mathrm{ml}^{-1}$.

\section{Statistical analysis}

Data analysis was performed using SAS version 8.01 computer program (SAS Institute Inc., Cary, NC). Results are quoted as arithmetic mean \pm SEM, and the level of significance was $P<0.05$.

The locations of ovarian structures (first dominant follicle, first ovulation or second dominant follicle) in relation to the previously gravid uterine horn were compared using chi-squared analysis or Fisher's exact test if cells contained fewer than five observations. Logistic regression was used to examine the effect of standard or high uterine bacterial contamination, or the pathogen group, on the location of ovarian structures, and to obtain odds ratios.

Survival analysis, using Cox regression models, was used to compare time intervals from calving to appearance of the first dominant follicle, the first dominant ovulatory follicle and to ovulation, between bacterial categories, between the ovarian location of the structures or between different bacterial pathogen groups.

The numbers of follicles were compared using MannWhitney or Kruskall-Wallis non-parametric tests for two or more variables, respectively. Follicle diameter, plasma oestradiol and $\mathrm{FSH}$ concentrations were compared by repeated measurements ANOVA using a mixed model (SAS, 1997). Data from day 7 after parturition, the start of the study, to day 16 , the mean day of ovulation for the first dominant follicle, were included in the analysis. Data were examined for normality using the Kolmogorov-Smirnoff test and for equality of variance using the Levene's test. Where appropriate, data were $\log _{10^{-}}$or square root-transformed to yield variance homogeneity. The explanatory variables were bacterial contamination category on days 7, 14, 21 and 28, pathogen group, location of the first dominant follicle, fate of the first dominant follicle and their interactions with time after parturition. A compound symmetry model best fitted the data, as determined using Akaike's information criterion. Post hoc tests were performed using Bonferonni's adjustment. 


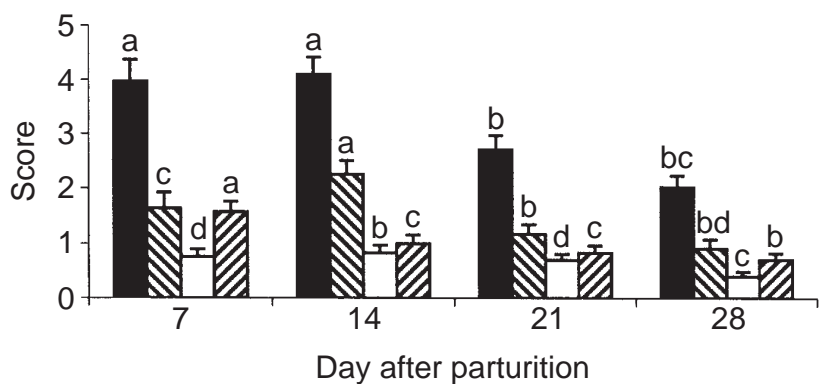

Fig. 1. Bacterial growth score from cows on days 7, 14, 21 and 28 for all bacteria $(\mathbf{\square})$, group 1 bacteria $(\mathbf{N})$, group 2 bacteria $(\square)$ and group 3 bacteria $(\boldsymbol{Z})$. Categories: (1) pathogens known to cause endometrial lesions; (2) other recognized uterine pathogens; and (3) bacteria not recognized as uterine pathogens. Values are mean \pm SEM. Within bacterial group, different superscripts indicate differences between days: ${ }^{\mathrm{ab}} P<0.001 ;{ }^{\mathrm{ac}}, \mathrm{bc} P<0.01 ;{ }^{\mathrm{cd}} P<0.05$.

\section{Results}

\section{Bacteriology}

Bacteria were isolated from uterine swabs in each animal at least once during the study. More than 30 different bacteria were identified and categorized by their potential pathogenicity (Table 1). No bacteria were isolated from uterine swabs collected from 5, 4, 9 and 13 animals on days 7, 14, 21 and 28, respectively. The mean \pm SEM bacterial growth score for each bacterial pathogenicity group is shown (Fig. 1) for uterine swabs collected on day 7, 14, 21 or 28. The ranges of total bacterial growth scores were $0-15,0-12,0-10$ and $0-9$ for days 7, 14, 21 and 28, respectively. The $75 \%$ quartile cut-off point to categorize cows into standard or high bacterial score groups for uterine swabs collected was score 6 on day 7 , score 6 on day 14 , score 4 on day 21 and score 3 on day 28. The mean bacterial score of the standard categories on days 7, 14, 21 and 28 was $2.2 \pm 0.2,2.7 \pm 0.2,1.6 \pm 0.2$ and $1.2 \pm 0.1$, respectively, and $8.4 \pm 0.6,7.7 \pm 0.4,5.5 \pm 0.4$ and $4.2 \pm 0.2$, respectively, for the high categories. The individual animals comprising the standard or high bacterial score categories on day $7,14,21$ or 28 were not always the same. However, 28 animals in the standard and seven in the high bacterial contamination categories were identical across the four periods.

\section{Location of events}

A wave of follicular development, with the emergence of a dominant follicle, was observed in all cows within 14 days of parturition. The location of ovarian events, but not their timing, differed significantly between the ipsilateral and contralateral ovaries (Table 2). However, the number of follicles $\geqslant 4 \mathrm{~mm}$ in diameter in the first postpartum follicular wave did not differ significantly between high or standard day 7 bacterial score categories in the ipsilateral ovary $(1.88 \pm 0.18$ versus $1.40 \pm 0.22$, respectively) or the contralateral ovary $(2.86 \pm 0.19$ versus $2.95 \pm 0.17$, respectively).
Logistic regression for the location of the first postpartum dominant follicle indicated that the standard or high bacterial category was significant on day $7(P<0.05)$, but not on days 14,21 or 28 . The high day 7 bacterial score category was 14.4 (odds ratio) times less likely to have a first dominant follicle in the ipsilateral ovary compared with the standard category (Fig. 2a). However, the location of the first dominant follicle did not differ significantly between animals in different bacterial pathogenicity groups on day 7 after parturition.

Ultrasonography revealed three possible fates for the first dominant follicle: ovulation $(n=48)$; regression followed by a second follicular wave $(n=10)$; or formation of a persistent follicle $(n=12)$. The frequency of the first dominant follicles that ovulated, regressed or persisted did not differ significantly between the standard and high bacterial categories on day 7 (37, 6 and 10 versus 11, 4 and 2, respectively), day 14 (33, 6 and 7 versus 15,4 and 5, respectively), day 21 (36, 6 and 11 versus 12, 4 and 1, respectively) or day 28 (40, 6 and 11 versus 8,4 and 1, respectively).

A second follicular wave was detected in 43 animals. The number of follicles $\geqslant 4 \mathrm{~mm}$ in diameter in the second postpartum follicular wave did not differ significantly between high or standard day 21 bacterial score categories in the ipsilateral ovary $(2.11 \pm 0.54$ versus $2.34 \pm 0.21)$ or in the contralateral ovary ( $2.89 \pm 0.45$ versus $2.44 \pm 0.28)$. Logistic regression for the location of the second postpartum dominant follicle indicated that the bacterial category was significant on day $21(P<0.05)$, but not on days 7,14 or 28 . The high day 21 bacterial score category was 6.0 (odds ratio) times less likely to have a first dominant follicle in the ipsilateral ovary compared with the standard category (Fig. 2b). However, the location of the second dominant follicle did not differ significantly between uterine pathogenicity groups.

\section{Timing of events}

The mean interval between calving and the first dominant follicle achieving dominance was $9.2 \pm 0.3$ days. The calving to follicular dominance interval was similar for the day 7 high bacterial score category and the standard bacterial score cows $(10.3 \pm 0.6$ versus $8.8 \pm 0.3$ days, respectively), and for the different bacterial pathogenicity groups. For animals in which the first dominant follicle ovulated, the mean interval from calving to ovulation was $15.7 \pm 0.7$ days. There was no significant difference in the calving to ovulation interval between cows with high or standard bacterial scores on day $7(16.4 \pm 1.4$ versus $15.4 \pm 0.8$ days, respectively) or on day $14(17.3 \pm 1.6$ versus $15.2 \pm 0.8$ days, respectively). An increase in plasma progesterone concentration to $>1 \mathrm{ng} \mathrm{ml}^{-1}$ was detected $3.2 \pm 0.2$ days after ovulation and did not differ significantly between bacterial score categories on days 7,14 or 21 . The interval from parturition to dominance of the second dominant follicle was $19.7 \pm 0.7$ days and, again, did not differ between bacterial score categories on days 7, 14 or 21 . 
Table 2. The location and timing of postpartum ovarian events ipsilateral and contralateral to the previously gravid uterine horn for 70 cows

\begin{tabular}{lcc}
\hline Event & Ipsilateral & Contralateral \\
\hline Number of first wave follicles $\geqslant 4$ mm in diameter & $1.74 \pm 0.15$ & $2.89 \pm 0.14^{* * *}$ \\
Number of animals with a first dominant follicle & 16 & $54^{* * *}$ \\
Number of first dominant follicles ovulated & 11 & $37^{* * *}$ \\
Number of second wave follicles $\geqslant 4$ mm in diameter & $2.29 \pm 0.20$ & $2.54 \pm 0.24$ \\
Number of animals with a second dominant follicle & 14 & $29 *$ \\
Calving to dominance interval: first dominant follicle (days) & $8.9 \pm 0.6$ & $9.3 \pm 0.4$ \\
Calving to first dominant follicle ovulation interval (days) & $14.0 \pm 1.2$ & $16.2 \pm 0.8$ \\
Days from first ovulation to plasma progesterone $>$ 1 ng ml-1 & $3.3 \pm 0.5$ & $3.1 \pm 0.2$ \\
Calving to dominance interval: second dominant follicle (days) & $20.0 \pm 1.4$ & $19.6 \pm 0.9$ \\
\hline
\end{tabular}

Values differ significantly between the ipsilateral and contralateral ovary: ${ }^{* * *} P<0.001 ; * P<0.05$.

\section{Follicle diameter}

The mean internal diameter of first dominant follicles increased each day between day 7 and day 16 after parturition $(P<0.0001)$. However, uterine bacterial score, ovarian location and the fate of the dominant follicle significantly influenced follicle diameter. The diameter of the first dominant follicle was smaller in animals with a high day 7 bacterial score compared with standard score cows $(P<0.001)$ and there was a significant interaction of bacterial score category with time $(P<0.05$, Fig. 3$)$. However, the influence of the bacterial pathogenicity group was not significant. The diameter of the first dominant follicle differed between follicles located in the ipsilateral ovary and follicles located in the contralateral ovary $(P<0.05)$, and the interaction of location with time was also significant $(P<0.05$, Fig. 4). There was no difference in follicle diameter between follicles that persisted and those that ovulated or regressed. However, between day 9 and day 13 after parturition, the first dominant follicle was smaller before regression compared with follicles that ovulated $(P<0.05$, Fig. 5). The interaction of the fate of the dominant follicle and time was not significant.

\section{Plasma oestradiol concentration}

Plasma oestradiol concentration increased between day 7 and day 16 after parturition $(P<0.0001)$. In addition, there were significant interactions of day $\times$ day 7 bacterial category $(P<0.05$, Fig. 3$)$, and day $\times$ fate of the first dominant follicle $(P<0.05$, Fig. 5). There was no significant effect of the bacterial pathogen group or the location of the first dominant follicle (Fig. 4). On days 15 and 16, plasma oestradiol concentrations were lower in animals with a high day 7 bacterial score (Fig. 3). Oestradiol concentration was also lower between day 12 and day 15 in animals in which the first dominant follicle regressed compared with animals in which the follicle ovulated or persisted (Fig. 5).

\section{Plasma FSH concentration}

Plasma FSH concentration between day 7 and day 16 after parturition differed significantly between days after
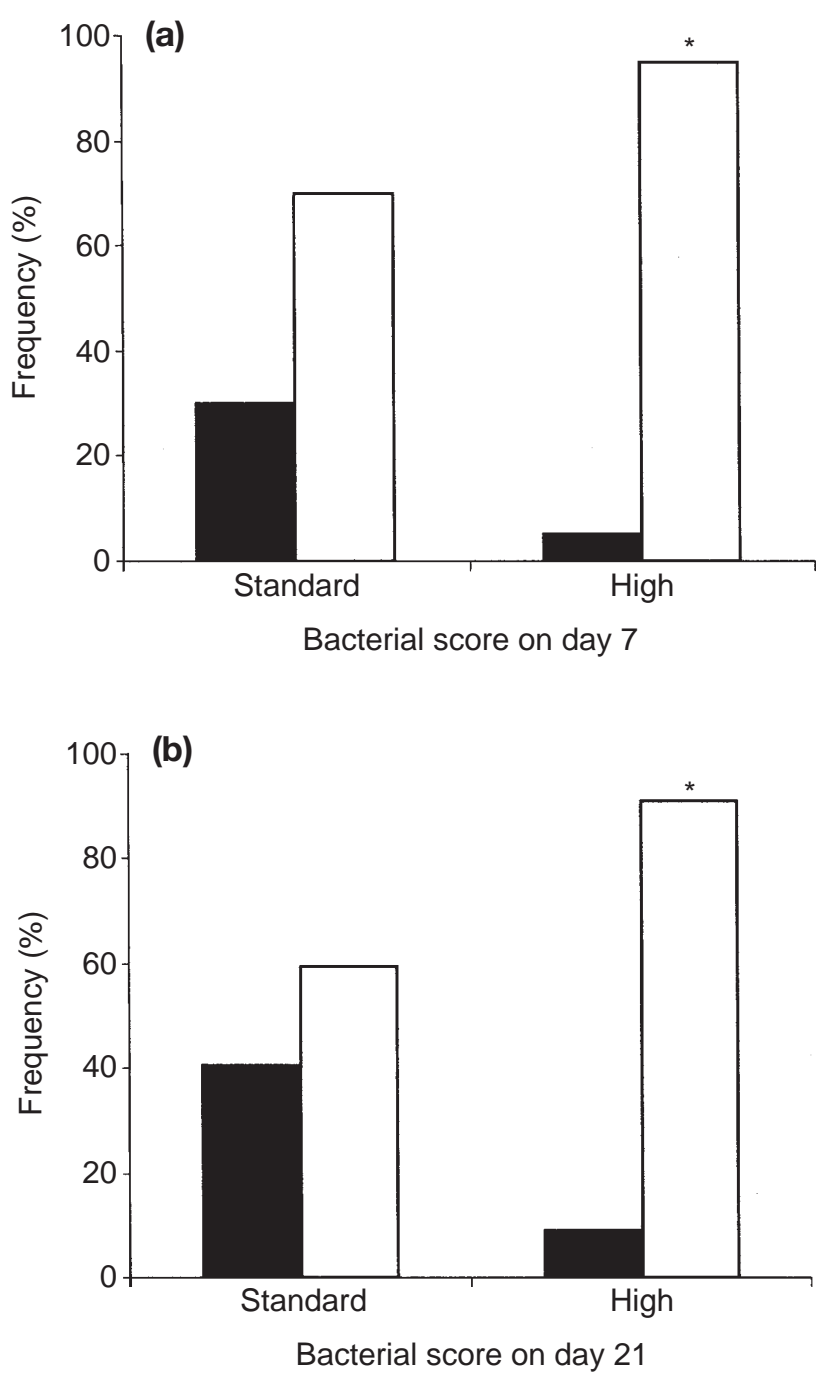

Fig. 2. Frequency (\%) of (a) first postpartum dominant follicles and (b), where observed, second dominant follicles in the ipsilateral ( $\square$ ) or contralateral $(\square)$ ovary of cows with standard or high bacterial scores on (a) day 7 (standard: $n=50$; high: $n=20$ ) and (b) day 21 (standard: $n=32$; high: $n=11$ ) after parturition. *Frequencies differ between ovaries within bacterial score category $(P<0.05)$. 

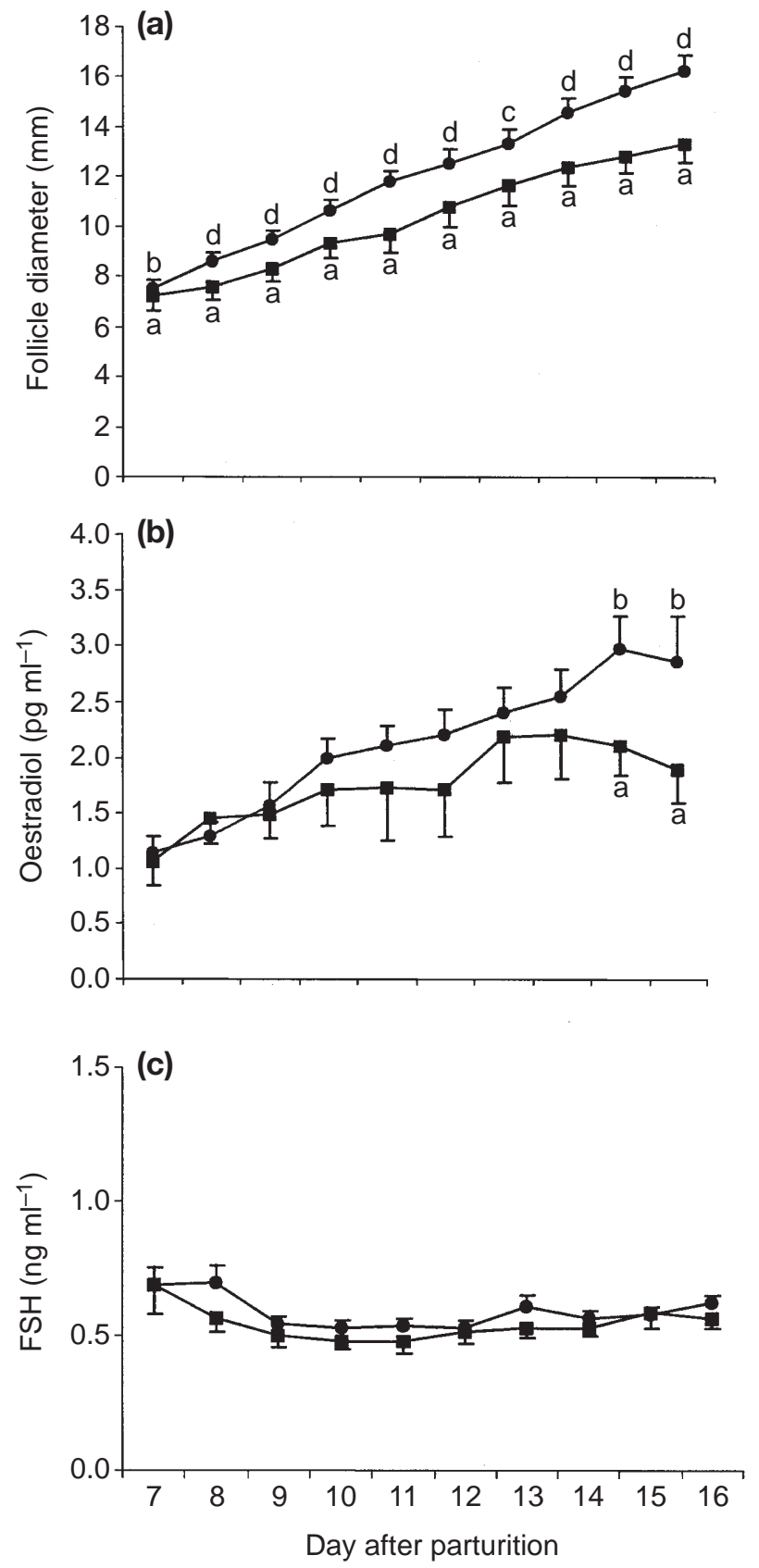

Fig. 3. (a) Diameter of first dominant follicle, (b) plasma oestradiol concentration and (c) plasma FSH concentration between day 7 and day 16 after parturition for cows in which there was standard $(\bullet$ $n=50)$ or high $(\boldsymbol{\square}, n=20)$ uterine bacterial contamination on day 7 . Values are mean \pm SEM. Within a day, values differ between bacterial contamination categories: $\quad{ }^{\mathrm{ab}} P<0.05 ; \quad$ ac $P<0.01$; ad $P<0.001$.

parturition $(P<0.05$, Figs 3,4 and 5$)$. FSH concentration was highest on day 7 , decreased between day 8 and day 12 , and subsequently increased between day 13 and day 16 . Additional significant variables were the fate of the first dominant follicle $(P<0.01$, Fig. 5) and the interaction of day $\times$ fate of the dominant follicle $(P<0.01)$. However, plasma FSH concentration did not differ significantly
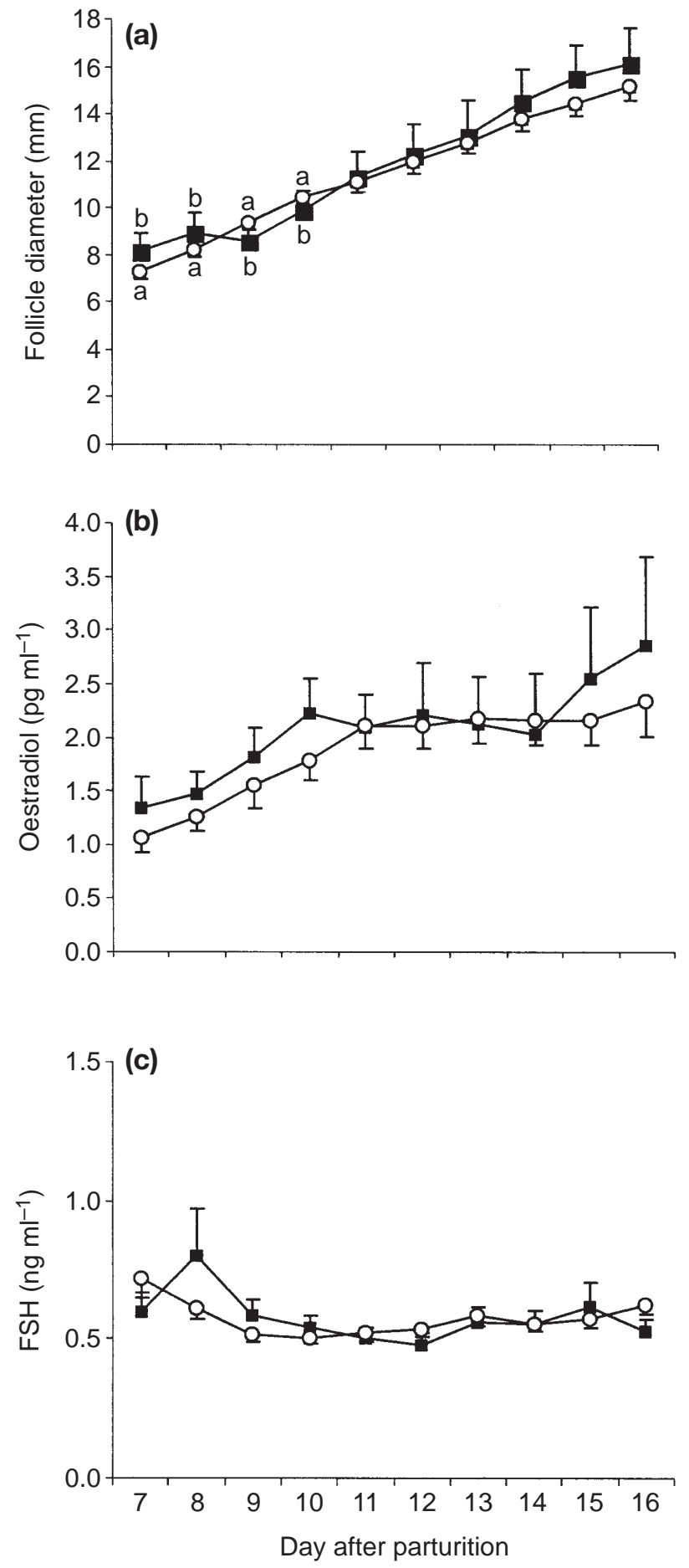

Fig. 4. (a) Diameter of first dominant follicle, (b) plasma oestradiol concentration and (c) plasma FSH concentration between day 7 and day 16 after parturition for cows in which the dominant follicle was located in the ipsilateral $(\boldsymbol{\square}, n=16)$ or contralateral $(\bigcirc$,

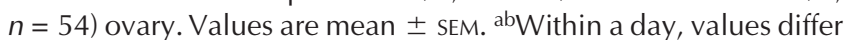
between ovary groups $(P<0.05)$.

between animals with standard or high bacterial scores on day 7 (Fig. 3), between bacterial pathogenicity groups, or between animals in which the first dominant follicle was located in the ipsilateral or contralateral ovary (Fig. 4). 

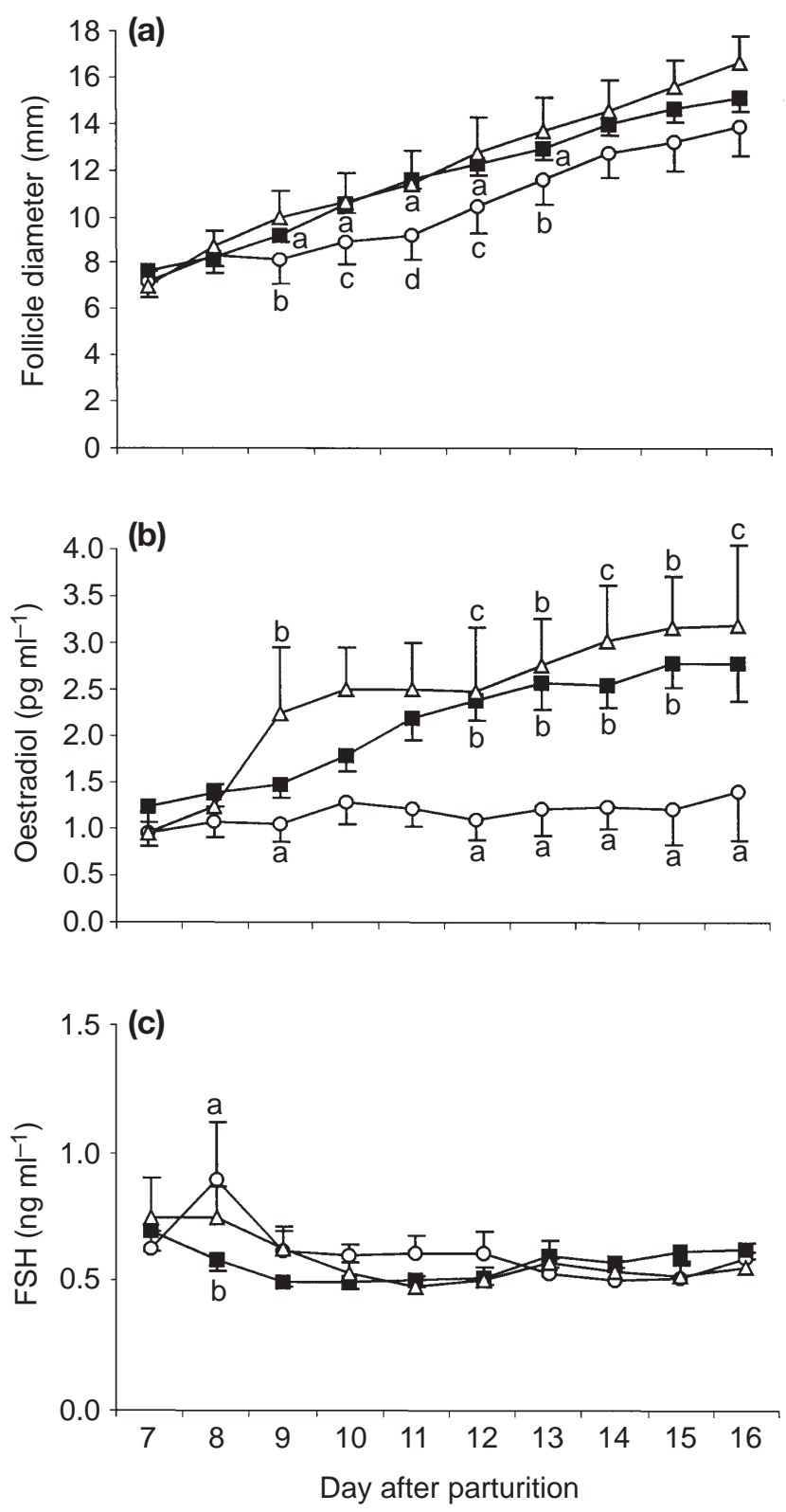

Fig. 5. (a) Diameter of first dominant follicle diameter, (b) plasma oestradiol concentration and (c) plasma FSH concentration between day 7 and day 16 after parturition for cows in which the dominant follicle ovulated $(\boldsymbol{\square}, n=48)$, regressed $(\bigcirc, n=10)$ or persisted $(\triangle, n=12)$. Values are mean \pm SEM. Within a day, values differ between follicle groups: ${ }^{a b} P<0.05$; ${ }^{a c} P<0.01$; ad $P<0.001$.

\section{Discussion}

The present study provides evidence that after parturition uterine bacterial contamination has a contemporaneous effect on ovarian folliculogenesis. Spontaneous uterine bacterial contamination influenced the location of ovarian dominant follicle selection, but not follicle wave emergence. In addition, uterine bacterial contamination suppressed dominant follicle growth and function.
A postpartum transient increase in plasma FSH concentration preceded the emergence of the first postpartum follicular wave and subsequent selection of a dominant follicle during the following phase of decreasing FSH concentrations (Beam and Butler, 1997; Crowe et al., 1998). Similarly, in the present study, after parturition a wave of follicles $\geqslant 4 \mathrm{~mm}$ in diameter emerged and a first dominant follicle was selected in each animal irrespective of the severity of uterine bacterial contamination. Plasma FSH concentrations did not differ between standard or high bacterial score categories, and there was no effect on the number of follicles $\geqslant 4 \mathrm{~mm}$ in diameter that emerged in each ovary. However, similar to previous observations, fewer follicles $\geqslant 4 \mathrm{~mm}$ in diameter emerged and fewer first dominant follicles were selected in the ovary ipsilateral to the previously gravid uterine horn (Kamimura et al., 1993; Sheldon et al., 2002). During the second follicular wave after parturition, there was no difference between the ovaries for the number of follicles $\geqslant 4 \mathrm{~mm}$ in diameter emerging, although fewer second dominant follicles were selected in the ipsilateral ovary. These observations support our previous findings that the effect on folliculogenesis in the ipsilateral ovary decreases with increasing time after parturition, in parallel with uterine involution and disappearance of the corpus luteum of pregnancy (Sawyer, 1995; Sheldon et al., 2000). However, removal of the corpus luteum of pregnancy before parturition did not affect the asymmetric distribution of dominant follicles between the ovaries (Sheldon et al., 2002). Thus, it is possible that uterine bacterial contamination after parturition may determine the location of dominant follicle selection.

In the present study, when uterine bacterial growth scores were high on day 7 or day 21 , few first or second dominant follicles were selected in the ipsilateral ovary, respectively. These observations indicate that uterine bacterial contamination may have a localized effect preventing dominant follicle selection in the ipsilateral ovary. Similarly, cows with retained fetal membranes, which are likely to be associated with increased uterine bacterial contamination, had less follicular activity in the ipsilateral ovary, although the presence of dominant follicles was not identified (Risco et al., 1994). The effect of uterine bacterial contamination appeared to be short term. The uterine bacterial scores on days 7 and 21 were contemporaneous with the time of first and second dominant follicle selection on about days 9 and 20, respectively. Bacterial scores at other times were not significant. Furthermore, the individual animals comprising the high score categories on days 7 and 21 were not exactly the same.

There are two potential mechanisms by which uterine bacterial contamination could have a localized effect on the ipsilateral ovary. Firstly, bacterial load or the induced inflammatory response may differ between the two uterine horns. Alternatively, the concentration of inflammatory mediators reaching the ipsilateral ovary may be higher than the concentration reaching the contralateral ovary because 
of the greater blood flow to and from the gravid uterine horn (Ford et al., 1979). Most animals had bacterial contamination of the uterus within 2 weeks of parturition, so it was not possible to determine whether the inflammatory response was the sole mechanism for the disparity in the pattern of folliculogenesis between the two ovaries.

The precise mechanism by which inflammatory mediators could influence ovarian events has not been determined. However, intravenous or intracerebral infusion of endotoxin or the cytokine interleukin 1 (IL-1) disrupts the follicular phase of the oestrous cycle in several species (Peter et al., 1989; Rivest et al., 1993; Battaglia et al., 1999). A contemporaneous effect of inflammatory mediators was to be expected, as there is acute inhibition of hypothalamic GnRH release and pituitary LH secretion (Rivest et al., 1993; Williams et al., 2001). However, these neuroendocrine mechanisms do not fully explain the observations of a localized effect on the ipsilateral ovary in the present study, although evidence has been provided for a direct effect of inflammatory mediators at the ovary by suppression of oestradiol secretion in the presence of adequate plasma LH concentrations (Xiao et al., 1998; Battaglia et al., 2000).

In addition to the effect of the high day 7 uterine bacterial score on dominant follicle location, follicles grew more slowly and produced lower plasma oestradiol concentrations. A significant difference in plasma oestradiol concentration between dominant follicles in the standard or high day 7 bacterial score categories was not detected until days 15-16, when the difference in follicle diameter was maximal. The effect of uterine bacterial contamination on follicle growth and function could be a centralized effect mediated by disruption of $\mathrm{LH}$ secretion, or a direct effect on the ovary (Battaglia et al., 2000). Decreased plasma LH concentration reduced the growth rate and oestradiol secretion of dominant follicles after follicle selection (Ginther et al., 2001). However, in the present study, the effect on follicle growth rate was evident at a diameter of $<8.5 \mathrm{~mm}$, the diameter for deviation between dominant and subordinate follicles (Ginther et al., 1999). Furthermore, although inflammatory challenge disrupts ovulation by perturbing the $\mathrm{LH}$ surge, the proportion of dominant follicles ovulating was not affected by spontaneous uterine bacterial contamination in the present study.

Although there were small differences in diameter between dominant follicles in the ipsilateral and contralateral ovaries before dominance, subsequent follicle diameters were similar. In addition, follicle function as determined by plasma oestradiol concentrations was similar for both ovaries, and the interval from parturition to ovulation was similar. These observations indicate that dominant follicles in the ipsilateral ovary were probably at least as functionally competent as follicles in the contralateral ovary.

Important uterine pathogenic bacteria are associated with more severe clinical disease, increased endometrial inflammation and reduced fertility (Farin et al., 1989; Bonnett et al., 1993). In particular, Arcanobacterium pyogenes,
Fusobacterium necrophorum and Prevotella spp act synergistically to cause more severe clinical signs (Ruder et al., 1981; Olson et al., 1984). In the present study, although there was an effect of bacterial load on folliculogenesis, the importance of uterine bacterial pathogens was not significant. This finding indicates that the inflammatory response to the amount of bacterial contamination is probably more important than the presence of particular bacterial species.

In conclusion, there was no effect of uterine bacterial contamination on plasma FSH concentration and ovarian follicle wave emergence. However, spontaneous bacterial contamination of the postpartum uterus influenced the ovarian location for dominant follicle selection. Contemporaneous high bacterial contamination was associated with fewer first and second dominant follicles in the ovary ipsilateral to the previously gravid uterine horn. In addition, dominant follicle growth was slower and oestradiol secretion was reduced in the presence of high bacterial contamination. The results of the present study provide evidence for a localized effect of uterine bacterial contamination on the ovary after parturition.

This study was supported by the Royal College of Veterinary Surgeons (Wilson) Scholarship in Production Animal Medicine, and a Royal Veterinary College Internal Grant to I.M.S. The authors thank Professor Mac Johnston for access to the dairy herd, and Angelika Von Heimendahl, Soujun Li, and Mark Whalley for assistance with sample collection. They also thank Vicky Harrison, Hilary Purcell and Jean Routley for technical assistance with hormone assays, and Maggie Bushnell for bacteriology. They acknowledge NIAMDD, Bethesda, MD for FSH assay reagents.

\section{References}

Barrow GI and Feltham RKA (1993) Cowan and Steel's Manual for the Identification of Medical Bacteria pp 1-331. Cambridge University Press, Cambridge

Battaglia DF, Beaver AB, Harris TG, Tanhehco E, Viguie C and Karsch FJ (1999) Endotoxin disrupts the estradiol-induced luteinizing hormone surge: interference with estradiol signal reading, not surge release Endocrinology 140 2471-2479

Battaglia DF, Krasa HB, Padmanabhan V, Viguie C and Karsch FJ (2000) Endocrine alterations that underlie endotoxin-induced disruption of the follicular phase in ewes Biology of Reproduction 62 45-53

Beam SW and Butler WR (1997) Energy balance and ovarian follicle development prior to the first ovulation postpartum in dairy cows receiving three levels of dietary fat Biology of Reproduction 56 133-142

Bonnett BN, Martin SW and Meek AH (1993) Associations of clinical findings, bacteriological and histological results of endometrial biopsy with reproductive performance of postpartum dairy cows Preventive Veterinary Medicine 15 205-220

Crowe MA, Padmanabhan V, Mihm M, Beitins IZ and Roche JF (1998) Resumption of follicular waves in beef cows is not associated with periparturient changes in follicle-stimulating hormone heterogeneity despite major changes in steroid and luteinizing hormone concentrations Biology of Reproduction 58 1445-1450

Dobson H, Ribadu AY, Noble KM, Tebble JE and Ward WR (2000) Ultrasonography and hormone profiles of adrenocorticotrophic hormone (ACTH)-induced persistent ovarian follicles (cysts) in cattle Journal of Reproduction and Fertility 120 405-410

Dufour JJ and Roy GL (1985) Distribution of ovarian follicular populations 
in the dairy cow within 35 days after parturition Journal of Reproduction and Fertility 73 229-235

Elliot L, McMahon KJ, Gier HT and Marion GB (1968) Uterus of the cow after parturition: bacterial content American Journal of Veterinary Research 29 77-81

Farin PW, Ball L, Olson JD, Mortimer RG, Jones RL, Admey WS and McChesney AE (1989) Effect of Actinomyces pyogenes and gramnegative bacteria on the development of bovine pyometra Theriogenology 31 979-989

Ford SP, Chenault JR and Echternkamp SE (1979) Uterine blood flow of cows during the oestrous cycle and early pregnancy: effect of the conceptus on the uterine blood supply Journal of Reproduction and Fertility 56 53-62

Ginther OJ, Kot K, Kulick LJ, Martin S and Wiltbank MC (1996) Relationships between FSH and ovarian follicular waves during the last six months of pregnancy in cattle Journal of Reproduction and Fertility 108 271-279

Ginther OJ, Bergfelt DR, Kulick LJ and Kot K (1999) Selection of the dominant follicle in cattle: establishment of follicle deviation in less than 8 hours through depression of FSH concentrations Theriogenology $\mathbf{5 2}$ 1079-1093

Ginther OJ, Bergfelt DR, Beg MA and Kot K (2001) Follicle selection in cattle: role of luteinizing hormone Biology of Reproduction 64 197-205

Horadagoda NU, Knox KMG, Gibbs HA, Reid SWJ, Horadagoda A, Edwards SER and Eckersall PD (1999) Acute phase proteins in cattle: discrimination between acute and chronic inflammation Veterinary Record 144 437-441

Kamimura S, Ohgi T, Takahashi M and Tsukamoto T (1993) Postpartum resumption of ovarian activity and uterine involution monitored by ultrasonography in Holstein cows Journal of Veterinary Medicine and Science 55 643-647

Laven RA, Biggadike HJ, Proven MJ, Halfacre S and Tickle LR (2000) Changes in vaginal microbiology associated with the use of progesterone-releasing intravaginal devices Veterinary Record 146 760-762

Mann GE, Lamming GE and Fray MD (1995) Plasma oestradiol and progesterone during early pregnancy in the cow and the effects of treatment with buserelin Animal Reproduction Science 37 121-131

Noakes DE, Till D and Smith GR (1989) Bovine uterine flora post partum: a comparison of swabbing and biopsy Veterinary Record 124 563-564

Noakes DE, Wallace L and Smith GR (1991) Bacterial flora of the uterus of cows after calving on two hygienically contrasting farms Veterinary Record 128 440-442

Olson JD, Ball L, Mortimer RG, Farin PW, Adney WS and Huffman EM (1984) Aspects of bacteriology and endocrinology of cows with pyometra and retained foetal membranes American Journal of Veterinary Research 45 2251-2255

Peter AT and Bosu WTK (1988) Relationship of uterine infections and folliculogenesis in dairy cows during early puerperium Theriogenology 30 1045-1051

Peter AT, Bosu WTK and DeDecker RJ (1989) Suppression of preovulatory luteinizing hormone surges in heifers after intrauterine infusions of Escherichia coli endotoxin American Journal of Veterinary Research $\mathbf{5 0}$ 368-373

Risco CA, Drost M, Thatcher WW, Savio J and Thatcher MJ (1994) Effects of calving-related disorders on prostaglandin, calcium, ovarian activity and uterine involution in postpartum dairy cows Theriogenology $\mathbf{4 2}$ 183-203

Rivest S, Lee S, Attardi B and Rivier C (1993) The chronic intracerebroventricular infusion of interleukin- $1 \beta$ alters the activity of the hypothalamic-pituitary-gonadal axis of cycling rats. I. Effect on LHRH and gonadotropin biosynthesis and secretion Endocrinology 133 2424-2430

Ruder CA, Sasser RG, Williams RJ, Ely JK, Bull RC and Butler JE (1981) Uterine infections in the postpartum cow. II. Possible synergistic effect of Fusobacterium necrophorum and Corynebacterium pyogenes. Theriogenology 15 573-580

SAS Institute Inc. (1997) SAS/STAT Software: Changes and Enhancements Through Release 6.12 pp 571-702. SAS Institute Inc., Cary, NC

Sawyer HR (1995) Structural and functional properties of the corpus luteum of pregnancy Journal of Reproduction and Fertility Supplement 49 97-110

Scott PR, Murray LD and Penny CD (1992) A preliminary study of serum haptoglobin concentration as a prognostic indicator of ovine dystocia cases British Veterinary Journal 148 351-355

Sheldon IM, Noakes DE and Dobson H (2000) The influence of ovarian activity and uterine involution determined by ultrasonography on subsequent reproductive performance Theriogenology 54 409-419

Sheldon IM, Noakes DE and Dobson H (2002) Effect of the regressing corpus luteum of pregnancy on ovarian folliculogenesis after parturition in cattle Biology of Reproduction 66 266-271

Skinner JG, Brown RA and Roberts L (1991) Bovine haptoglobin response in clinically defined field conditions Veterinary Record 128 147-149

Williams CY, Harris TG, Battaglia DF, Viguie C and Karsch FJ (2001) Endotoxin inhibits pituitary responsiveness to gonadotrophin-releasing hormone Endocrinology 142 1915-1922

Xiao E, Xia-Zhang L, Barth A, Zhu J and Ferin M (1998) Stress and the menstrual cycle: relevance of cycle quality in the short- and long-term response to a 5-day endotoxin challenge during the follicular phase in the rhesus monkey Journal of Clinical Endocrinology and Metabolism $832454-2460$

Received 28 November 2001.

First decision 6 February 2002.

Accepted 4 March 2002. 